OFeldman M, Ginsburg I.

\title{
A Novel Hypothetical Approach to Explain the Mechanisms of Pathogenicity of Rheumatic Arthritis
}

\section{Mark Feldman, Isaac Ginsburg}

Institute for Dental Sciences, the Hebrew University - Hadassah Faculty of Dental Medicine, Ein Kerem Campus, Jerusalem, Israel

\section{ABSTRACT}

The autoimmune disorder rheumatoid arthritis (RA) is a relapsing and chronic inflammatory disease that affects the synovial cells, cartilage, bone, and muscle. It is characterised by the accumulation of huge numbers of polymorphonuclear neutrophils (PMNs) and macrophages in the synovia. Auto-antibodies are deposited in the joint via the activity of highly cationic histones released from neutrophil extracellular traps (NETs) in a phenomenon termed NETosis. The cationic histones function as opsonic agents that bind to negatively charged domains in autoantibodies and complement compounds via strong electrostatic forces, facilitating their deposition and endocytosis by synovial cells. However, eventually the main cause of tissue damage is the plethora of toxic pro-inflammatory substances released by activated neutrophils recruited by cytokines. Tissue damage in RA can also be accompanied by infections which, upon bacteriolysis, release cell-wall components that are toxic to tissues. Some amelioration of the damaged cells and tissues in RA may be achieved by the use of highly anionic heparins, which can neutralize cationic histone activity, provided that these polyanions are co-administrated with anti-inflammatory drugs such as steroids, colchicine, or methotrexate, low molecular weight antioxidants, proteinase inhibitors, and phospholipase A2 inhibitors.

Mediterr J Rheumatol 2020;32(2):112-7

https://doi.org/10.31138/mjr.32.2.112

Article Submitted: 10 Jul 2020; Revised Form: 29 Sep 2020; Article Accepted: 15 Oct 2020; Available Online: 28 May 2021

Keywords: Rheumatoid arthritis, ROS, RNS, proteinase, heparinoid, fibrinolysis, phospholipase

\section{INTRODUCTION}

Rheumatoid arthritis (RA) is a severe autoimmune disorder that occurs in about $0.5-1 \%$ of the population. It

\section{Corresponding Author:}

Mark Feldman

Institute for Dental Sciences, The

Hebrew University - Hadassah

Faculty of Dental Medicine

Ein Kerem Campus, Jerusalem, Israel

Tel.: +97250688 8162

E-mail: markfel15@yahoo.com may lead to severe synovial, joint, cartilage and bone damage and dysfunction. Early diagnosis and treatment of RA can substantially slow the progression of joint damage in up to $90 \%$ of patients. Rheumatoid arthritis can also show systemic manifestations, such as cardiovascular, pulmonary, and skeletal disorders. ${ }^{1-5}$ However, the genetic environment that potentially leads to articular damage is still not fully understood. ${ }^{6}$

The hallmark of RA is deposition in the joints of rheumatoid factors, immune complexes, complement components $s^{7-10}$ and perivascular polymorphonuclear neutrophils (PMNs) and macrophage infiltration recruited via cytokines. ${ }^{11-16}$ These leukocytes become activated and can release a plethora of toxic pro-inflammatory agonists into the surroundings, which can synergistically attack and destroy synovial cells, cartilage and bone structures. 


\section{A NOVEL WORKING HYPOTHESIS IS PROPOSED TO EXPLAIN MECHANISMS GOVERNING RA PATHOGENICITY}

The present communication argues that highly cationic histones and additional polycations are delivered by neutrophil extracellular traps (NETs) in a process termed NETosis..$^{17-18}$ These polycations act like opsonins ${ }^{19}$ that bind, via strong electrostatic forces, to negatively charged domains in immune complexes and in complement components. This interaction facilitates their deposition, binding and internalization by synovial cells.

This novel proposal is based mainly on previous observations from our laboratories. We have shown that if haemolytic streptococci, Candida albicans ${ }^{20}$ and even whole cell nuclei ${ }^{21}$ were pre-coated (opsonised) with the cationic histone, they will not only bind to and be endocytosed by phagocytes such as neutrophils and macrophages, but also by endothelial cells, fibroblasts, and even synovial cells.

However, the main toxic agents found in the joints that can eventually destroy synovial cells, cartilage and bone are most probably mediated by the toxic actions of the plethora of pro-inflammatory compounds released by activated neutrophils and macrophages. These include reactive oxygen and nitrogen species, cationic proteinases, and the membrane-damaging phospholipases and lysophosphatides, ${ }^{22-36}$ besides the toxic products released by dying cells. ${ }^{37} \mathrm{It}$ is also of great interest to note that the mechanisms by which PMNs and macrophages destroy tissues are very similar to those mediated by group A haemolytic streptococci. ${ }^{38}$

\section{THE POSSIBLE ROLE PLAYED BY INFECTIONS IN RA PATHOGENICITY}

Microbial infections, which sometimes accompany RA, may also contribute to the pathogenicity of various autoimmune disorders. This is because both pathogenic and non-pathogenic microorganisms can undergo bacterioly$\mathrm{sis}^{39}$ induced either by the action of cationic lysozyme, ${ }^{40}$ or following treatment with certain bacteriolytic antibiotics. ${ }^{39}$ Bacteriolysis involves the release of the cell-membrane component lipoteichoic acid and cell-wall-derived peptidoglycans ${ }^{38}$ derived from Gram-positive bacteria and lipopolysaccharide (LPS) from Gram-negative ones. ${ }^{38}$ Several studies have also described the persistence of non-biodegradable streptococcal cell-wall components in macrophages causing chronic joint inflammation. ${ }^{41-45}$ Moreover, during serious infections, treatment with anti-tumour necrosis factor alpha (TNFa) may also accompany RA. ${ }^{46}$

\section{ROLE OF REACTIVE OXYGEN SPECIES (ROS) IN RA PATHOGENICITY}

Cationic proteinases and oxidants generated by activated leukocytes via NADPH oxidase, may be key prod- ucts in tissue destruction during inflammation, and, most probably, also in autoimmune disorders. ${ }^{47-58}$ Therefore, the clinical use of low-molecular-weight antioxidants such as ascorbate, $\mathrm{N}$-acetyl cysteine, glutathione, catalase, and antioxidant extracts from cranberries, lemon, and pomegranate. might be important in the early phases of RA, especially if also combined with the anti-proteinase aprotinin, and inhibitors of phospholipase A2 (PLA2) and lysophosphatides such as lecithin (see below).

\section{THE ROLE OF REACTIVE NITROGEN SPECIES (RNS) IN RA PATHOGENICITY}

PMN activation in inflamed tissue can result in the generation of nitric oxide generated by inducible nitric oxide synthase. The nitric oxide radical can then be transformed into the highly toxic peroxynitrite which may act together with ROS to cause cell and tissue damage..$^{59-62}$

\section{THE POSSIBLE ROLE OF PROTEINASES IN TISSUE DAMAGE IN RA}

ROS, RNS and proteinases are always found in the synovial fluid of patients suffering from RA, and may be pathogenic, causing tissue degradation. A large series of investigations, mostly using tissue cultures, have demonstrated the synergistic toxic effects of proteinases and ROS. ${ }^{19,21,22,24,25,29,30,33,63-65}$ In general, oxidized proteins are more susceptible to degradation by proteinase. ${ }^{65}$

\section{CAN THE HIGHLY ANIONIC HEPARIN AND HEPARINOIDS BE USED TO AMELIORATE TISSUE DAMAGE IN RA?}

To prevent the binding, deposition, and endocytosis of immune complexes and complement components in tissues mediated by the action of cationic opsonins, ${ }^{19}$ one might consider the administration to RA patients of the highly negatively charged heparin and heparinoids. ${ }^{66-70}$ These common drugs could neutralise the opsonic activity of the polycationic histone, thereby preventing the deposition of immune complexes and complement components in tissues. Heparinoids ${ }^{69}$ have also been found to prevent the binding of immune complexes containing nucleosomal antigens to the glomerular basement membrane, thereby delaying the onset of autoimmune nephritis, and heparin inhibits the proliferation of human RA synoviocytes through the nuclear factor (NF)-kB pathway. ${ }^{70}$

\section{ROLE OF BLOOD COAGULATION AND FIBRINOLYSIS IN RA PATHOGENICITY}

The severe injury to synovial cells in the joints of RA patients may lead to blood-vessel damage. The accumulation of plasma and its coagulation and fibrinolytic components may affect the pathological processes involved in tissue destruction in the synovial cells, cartilage, muscle, and bone ${ }^{71-76}$ Plasmin is a potent proteolytic enzyme that acts in concert with ROS, RNS, proteinases and 
membrane-perforating phospholipases released from activated PMNs to cause cell damage. ${ }^{22,23}$ Fibrinolysis may also be affected by polycations such as poly-L-lysine (a histone mimetic) and others. ${ }^{77}$

\section{ROLE OF PHOSPHOLIPASES IN RA PATHOGENICITY}

PLA2 activity in the serum and synovial fluids in RA

PLA2 released by activated PMNs is found in the sera and synovial fluids of RA patients, with a positive correlation between synovial fluid and matched sera. ${ }^{78-82}$ Human neutrophils that were pre-treated with subtoxic concentrations of PLA2-derived lysophosphatides acted synergistically with the neutrophil agonist phorbol myristate acetate (PMA), immune complexes, cationic poly-L-histidine, phytohemagglutinin, and $\mathrm{N}$-formyl methionine-leucyl-phenylalanine (f-MLP) to cause enhanced generation of superoxide $\left(\mathrm{O}_{2}{ }^{-}\right)$. The lysophosphatide compounds bind strongly to the neutrophils and could not be washed away. The lysophosphatides that collaborated with agonists to stimulate $\mathrm{O}_{2}{ }^{-}$generation were also highly haemolytic towards human red blood cells. $\mathrm{O}_{2}-$ generation was also markedly enhanced when substimulatory amounts of arachidonic acid or eicosapentaenoic acid were added to PMNs in the presence of a variety of agonists. ${ }^{83}$ These data suggest that in addition to long-chain fatty acids, only those lysophosphatides compounds that possess fatty acids with more than 10 carbons and that are also highly haemolytic, can cause enhanced generation of $\mathrm{O}_{2}{ }^{-}$in stimulated PMNs.

\section{ARE THERE ANY SPECIFIC CLINICAL DRUGS, OTHER THAN ANIONIC HEPARINS, WHICH CAN AMELIORATE TISSUE DAMAGE IN RA PATIENTS?} Inhibition of cell damage in RA has been attempted clinically using drugs such as the anti-inflammatories methotrexate, colchicine, steroids, and cyclophosphamides, all known suppressors of the PMNs' main functions of chemotaxis and phagocytosis. Other suggested and tested drugs include hydroxychloroquine (Plaquenil), leflunomide (Arava), sulfasalazine (Azulfidine), and minocycline (Minocin). ${ }^{84,85}$ Chrysotherapy has also been recommended. ${ }^{86}$ However, to date, no drug has been really shown to effectively suppress the severe damage seen in RA. The use of antibiotics in RA may have some value when a specific microorganism is identified, but only if bacteriolytic antibiotics are used. ${ }^{39}$

\section{CONCLUSIONS, AND WHERE DO WE GO FROM HERE?}

The present communication offers a novel approach to describe the possible mechanisms underlying the joint destruction that is a hallmark of RA pathogenicity. RA is a synergistic multifactorial autoimmune disease involving an interplay among a multiplicity of proinflammatory agonists generated by activated neutrophils and macrophages, reactive oxygen nitrogen species PLA2, lysophosphatides, autoimmune complexes, complement components, and highly positively charged histones generated by PMN NETosis. Unfortunately, no specific agents or agent combinations have been identified whose significant inhibition might alter the deleterious toxic effects leading to joint destruction.

\section{SUMMARY}

In summary, we have discussed several overlapping and successive steps in the development and progression of RA pathogenicity. These steps include:

1. Recruitment of huge numbers of neutrophils (PMNs) and macrophages to the synovial area via cytokines.

2. Release from PMN NETs (NETosis) of highly cationic toxic histones and formation of citrullinated histones.

3. Histone may function as a potent opsonic agent.

4. Through strong electrostatic forces, opsonins can interact with and bind to negatively charged domains on immune complexes and complement components, facilitating their binding, deposition, and possibly also internalisation, by synovial cells.

5. Recruited PMNs and macrophages adhering to synovial surfaces are activated and release a plethora of toxic proinflammatory agonists into the surrounding medium. These include cationic peptides, oxidants, proteinases, and membrane-perforating phospholipases, which can all act synergistically to destroy synovial cells, cartilage, and bone structures. Development of blood coagulation and fibrinolysis in the synovial fluid may be dealt with using anticoagulants and agents that inhibit fibrinolytic activity.

6. Highly anionic heparin and heparinoids, which neutralise polycations, may provide protection against tissue damage in RA, more so if combined with drugs such as steroids, methotrexate, and colchicine, all potent anti-inflammatory agents against the PMN and macrophage functions of chemotaxis and phagocytosis. Th1 cytokines may also be inhibited by drugs that affect leukocyte recruitment.

7. Non-bacteriolytic antibiotics may be used to treat infections in RA patients. Bacteriolysis should be avoided, as it can release the potent toxic cell-wall components lipoteichoic acid, peptidoglycan, and endotoxin.

8. Nonbiodegradable microbial cell-wall components that persist for long periods in macrophages in the joints may perpetuate chronic destructive arthritis.

9. Toxic oxidants may be controlled clinically by the low-molecular-weight anti-oxidants glutathione, ascorbate, and $\mathrm{N}$-acetyl cysteine, and by certain plant polyphenols.

10. Blood coagulation and fibrinolysis may be dealt with using the anticoagulant heparin and proteinase inhibitors. 11. The use of drug cocktails comprised of antioxidants, 
proteinase inhibitors, PLA2 inhibitors, highly anionic heparin to inhibit one of the major agonists-histones, is recommended, if also combined with drugs such as steroids. Clinically, this might be a complicated task, necessitating the use of appropriate animal models and the permission to use such cocktails clinically, which can only be obtained following highly expensive clinical trials in humans.

\section{CONFLICT OF INTEREST}

The authors declare no conflict of interest.

\section{AUTHOR CONTRIBUTIONS}

All authors contributed equally.

\section{ACKNOWLEDGEMENTS}

This study is supported by an endowment fund donated by the late Dr. SM Robbins of Cleveland, Ohio, USA.

\section{REFERENCES}

1. Mclnnes IB, Schett $G$. The pathogenesis of rheumatoid arthritis. New Engl J Med 2011;365(23):2205-19.

2. Choy E. Understanding the dynamics: pathways involved in the pathogenesis of rheumatoid arthritis. Rheumatology 2012;51Suppl 5:v3-11.

3. Calabresi E, Petrelli F, Bonifacio A, Puxeddu I, Alunno A. One year in review 2018: pathogenesis of rheumatoid arthritis. Clin Exp Rheumatol 2018;36(2):175-84.

4. Aletaha D, Smolen JS. Diagnosis and management of rheumatoid arthritis: a review. JAMA 2018;320(13):1360-72.

5. Mayadas TN, Tsokos GC, Tsuboi N. Mechanisms of immune complex-mediated neutrophil recruitment and tissue injury. Circulation 2009;120(20):2012-24.

6. Firestein GS. Pathogenesis of rheumatoid arthritis: the intersection of genetics and epigenetics. Trans Am Clin Climatol Assoc 2018;129:171.

7. Derksen V, Huizinga T, van der Woude D. The role of autoantibodies in the pathophysiology of rheumatoid arthritis. Semin Immunopathol 2017;39(4):437-46

8. Low J, Moore T. A role for the complement system in rheumatoid arthritis. Curr Pharm Des 2005;11(5):655-70.

9. Monach PA, Hueber W, Kessler B, Tomooka BH, BenBarak M, Simmons BP, et al. A broad screen for targets of immune complexes decorating arthritic joints highlights deposition of nucleosomes in rheumatoid arthritis. Proc Natl Acad Sci USA 2009;106(37):1586772.

10. Steiner G, Smolen J. Autoantibodies in rheumatoid arthritis and their clinical significance. Arthritis Res Ther 2002;4(2):S1.

11. Brennan FM, Mclnnes IB. Evidence that cytokines play a role in rheumatoid arthritis. J Clin Invest 2008;118(11):3537-45.

12. Brzustewicz E, Bryl E. The role of cytokines in the pathogenesis of rheumatoid arthritis - practical and potential application of cytokines as biomarkers and targets of personalized therapy. Cytokine 2015;76(2):527-36.

13. Cecchi I, de la Rosa IA, Menegatti E, Roccatello D, Collantes-Estevez E, Lopez-Pedrera C, et al. Neutrophils: novel key players in rheumatoid arthritis. Current and future therapeutic targets. Autoimmun Rev 2018;17(11):1138-49.

14. Feldmann M, Brennan FM, Maini RN. Role of cytokines in rheumatoid arthritis. Annu Rev Immunol 1996;14(1):397-440.

15. Kaplan MJ. Role of neutrophils in systemic autoimmune diseases. Arthritis Res Ther 2013;15(5):219.

16. Wright HL, Moots RJ, Edwards SW. The multifactorial role of neutrophils in rheumatoid arthritis. Nat Rev Rheumatol 2014;10(10):593.
17. Brinkmann V, Zychlinsky A. Neutrophil extracellular traps: Is immunity the second function of chromatin? J Cell Biol 2012;198(5):77383.

18. Yang $\mathrm{H}$, Biermann MH, Brauner JM, Liu Y, Zhao Y, Herrmann M. New insights into neutrophil extracellular traps: mechanisms of formation and role in inflammation. Front Immunol 2016;7:302.

19. Ginsburg I. Cationic polyelectrolytes: a new look at their possible roles as opsonins, as stimulators of respiratory burst in leukocytes, in bacteriolysis, and as modulators of immune-complex diseases (a review hypothesis). Inflammation 1987;11(4):489-515.

20. Ginsburg I, Sela MN, Morag A, Ravid Z, Duchan Z, Ferne M, et al. Role of leukocyte factors and cationic polyelectrolytes in phagocytosis of group a streptococci and Candida albicans by neutrophils, macrophages, fibroblasts and epithelial cells. Inflammation 1981;5(4):289-312.

21. Hubner G, Voigt W, Schlumberger H, Ginsburg I. Poly-L-arginine 'opsonizes' nuclei for phagocytosis by mouse fibroblasts. IRCS Med Sci 1985;13(10):934-5.

22. Weiler JM, Edens RE, Linhardt R, Kapelanski D. Heparin and modified heparin inhibit complement activation in vivo. J Immunol 1992;148(10):3210-5

23. Ginsburg I, Kohen R. Invited review: Cell damage in inflammatory and infectious sites might involve a coordinated "cross-talk" among oxidants, microbial haemolysins and ampiphiles, cationic proteins, phospholipases, fatty acids, proteinases and cytokines (an overview). Free Radic Res 1995;22(6):489-517.

24. Ginsburg I. Could synergistic interactions among reactive oxygen species, proteinases, membrane-perforating enzymes, hydrolases, microbial hemolysins and cytokines be the main cause of tissue damage in infectious and inflammatory conditions? Med Hypotheses 1998;51(4):337-46.

25. Varani J, Ginsburg I, Schuger L, Gibbs D, Bromberg J, Johnson K, et al. Endothelial cell killing by neutrophils. Synergistic interaction of oxygen products and proteases. Am J Pathol 1989;135(3):435.

26. Ginsburg I, Kohen R. Synergistic effects among oxidants, membrane-damaging agents, fatty acids, proteinases, and xenobiotics: killing of epithelial cells and release of arachidonic acid. Inflammation 1995;19(1):101-18.

27. Kolaczkowska E, Kubes P. Neutrophil recruitment and function in health and inflammation. Nat Rev Immunol 2013;13(3):159-75.

28. Baird BR, Cheronis JC, Sandhaus RA, Berger EM, White CW, Repine JE. $\mathrm{O}_{2}$ metabolites and neutrophil elastase synergistically cause edematous injury in isolated rat lungs. J Appl Physiol 1986;61(6):2224-9.

29. Henson P, Johnston R. Tissue injury in inflammation. Oxidants, proteinases, and cationic proteins. J Clin Invest 1987;79(3):669-74.

30. Rodell T, Cheronis J, Repine J. Endothelial cell xanthine oxidase-derived toxic oxygen metabolites contribute to acute lung injury from neutrophil elastase. Chest 1988;93(3):146S.

31. Lichtenstein AK, Ganz T, Selsted ME, Lehrer RI. Synergistic cytolysis mediated by hydrogen peroxide combined with peptide defensins. Cell Immunol 1988;114(1):104-16.

32. Ginsburg I, Gibbs DF, Schuger L, Johnson KJ, Ryan US, Ward PA, et al. Vascular endothelial cell killing by combinations of membrane-active agents and hydrogen peroxide. Free Radic Biol Med 1989;7(4):369-76.

33. Ginsburg I, Misgav R, Pinson A, Varani J, Ward P, Kohen R. Synergism among oxidants, proteinases, phospholipases, microbial hemolysins, cationic proteins, and cytokines. Inflammation 1992;16(5):519-38.

34. Ginsburg I, Mitra RS, Gibbs DF, Varani J, Kohen R. Killing of endothelial cells and release of arachidonic acid. Inflammation. 1993;17(3):295-319.

35. Lehr H, Arfors K. Mechanisms of tissue damage by leukocytes. Curr Opin Hematol 1994;1(1):92-9.

36. Dallegri F, Ottonello L. Tissue injury in neutrophilic inflammation. Inflamm Res 1997;46(10):382-91.

37. Ginsburg I, Korem M, Koren E, Varani J. Pro-inflammatory agents released by pathogens, dying host cells, and neutrophils act syner- 
gistically to destroy host tissues: a working hypothesis. J Inflamm Res 2019;12:35.

38. Ginsburg I, Ward PA, Varani J. Can we learn from the pathogenetic strategies of group A hemolytic streptococci how tissues are injured and organs fail in post-infectious and inflammatory sequelae? FEMS Immunol Med Microbiol 1999;25(4):325-38.

39. Ginsburg I, Koren E. Bacteriolysis - a mere laboratory curiosity? Crit Rev Microbiol 2018;44(5):609-18.

40. Wecke J, Lahav M, Ginsburg I, Giesbrecht P. Cell wall degradation of Staphylococcus aureus by lysozyme. Arch Microbiol 1982;131(2):116-23.

41. Schwab JH, Cromartie WJ, Ohanian SH, Craddock JG. Association of experimental chronic arthritis with the persistence of group A streptococcal cell walls in the articular tissue. J Bacterio 1967;94(5):1728-35

42. Ginsburg I. Can chronic and self-perpetuating arthritis in the human be caused by arthrotropic undegraded microbial cell wall constituants? A working hypothesis. Rheumatol Rehab 1977;16(3):141-9.

43. Crofford L, Wilder R. Streptococcal cell wall antigens and rheumatoid arthritis. In: Smolen JS, Kalden JR, Maini RN, editors. Rheumatoid arthritis - recent research advances. Berlin: Springer; 1992. p. 202-15.

44. Ginsburg I, Zor U, Floman Y. Experimental models of streptococcal arthritis: pathogenetic role of streptococcal products and prostaglandins and their modification by anti-inflammatory agents. Exp Models Chron Inflamm Dis 1977;6:256-99.

45. Favalli EG, Desiati F, Atzeni F, Sarzi-Puttini P, Caporali R, Pallavicin $\mathrm{FB}$, et al. Serious infections during anti-TNFa treatment in rheumatoid arthritis patients. Autoimmun Rev 2009;8(3):266-73.

46. Feldmann M. Development of anti-TNF therapy for rheumatoid arthritis. Nat Rev Immunol 2002;2(5):364-71.

47. Halliwell B, Gutteridge JM. Free radicals in biology and medicine. Oxford, UK: Oxford University Press; 2015

48. Gutteridge JM, Halliwell B. Mini-review: Oxidative stress, redox stress or redox success? Biochem Biophys Res Commun 2018;502(2):183-6.

49. Gelderman KA, Hultqvist M, Olsson LM, Bauer K, Pizzolla A, Olofsson $\mathrm{P}$, et al. Rheumatoid arthritis: the role of reactive oxygen species in disease development and therapeutic strategies. Antiox Redox Signal 2007:9(10):1541-68.

50. Abbas M, Monireh $\mathrm{M}$. The role of reactive oxygen species in immunopathogenesis of rheumatoid arthritis. Iran J Allergy Asthma Immunol 2008;7(4):195-202.

51. Quiñonez-Flores CM, González-Chávez SA, Del Río Nájera D Pacheco-Tena C. Oxidative stress relevance in the pathogenesis of the rheumatoid arthritis: a systematic review. BioMed Res Int 2016;2016:6097417.

52. Hitchon CA, El-Gabalawy HS. Oxidation in rheumatoid arthritis. Arthritis Res Ther 2004;6(6):265.

53. Taraza C, Mohora M, Vârgolici B, Dinu V. Importance of reactive oxygen species in rheumatoid arthritis. Rom J Intern Med 1997;35(14):89-98.

54. Yoo S-J, Go E, Kim Y-E, Lee S, Kwon J. Roles of reactive oxygen species in rheumatoid arthritis pathogenesis. J Rheum Dis 2016;23(6):340-7.

55. Mateen S, Moin S, Khan AQ, Zafar A, Fatima N. Increased reactive oxygen species formation and oxidative stress in rheumatoid arthritis. PLoS One 2016 Apr 4;11(4):e0152925.

56. Stadtman ER, Berlett BS. Reactive oxygen-mediated protein oxidation in aging and disease. Drug Metab Rev 1998;30(2):225-43.

57. Afonso V, Champy R, Mitrovic D, Collin P, Lomri A. Reactive oxygen species and superoxide dismutases: role in joint diseases. Joint Bone Spine 2007;74(4):324-9.

58. Yoo S-J, Kang S, Kim J, Yoo I, Park C. THU0093 NADPH oxidases associated production of reactive oxygen species in rheumatoid arthritis. Ann Rheum Dis 2018;77:268.

59. Nagy G, Koncz A, Telarico T, Fernandez D, Érsek B, Buzás E, et al. Central role of nitric oxide in the pathogenesis of rheumatoid arthritis and sysemic lupus erythematosus. Arthritis Res Ther
2010;12(3):210

60. Weinberg JB, Granger DL, Pisetsky DS, Seldin MF, Misukonis MA, Mason SN, et al. The role of nitric oxide in the pathogenesis of spontaneous murine autoimmune disease: increased nitric oxide production and nitric oxide synthase expression in MRL-lpr/lpr mice, and reduction of spontaneous glomerulonephritis and arthritis by orally administered NG-monomethyl-L-arginine. J Exp Med 1994;179(2):651-60.

61. McCartney-Francis N, Allen JB, Mizel DE, Albina JE, Xie Q, Nathan CF, et al. Suppression of arthritis by an inhibitor of nitric oxide synthase. J Exp Med 1993;178(2):749-54.

62. Bauerova K, Bezek S. Role of reactive oxygen and nitrogen species in etiopathogenesis of rheumatoid arthritis. Gen Physiol Biophys 2000;18:15-20.

63. Rengel Y, Ospelt C, Gay S. Proteinases in the joint: clinical relevance of proteinases in joint destruction. Arthritis Res Ther 2007;9(5):221.

64. Momohara S, Kashiwazaki S, Inoue K, Saito S, Nakagawa T. Elastase from polymorphonuclear leukocyte in articular cartilage and synovial fluids of patients with rheumatoid arthritis. Clin Rheumatol 1997;16(2):133-9.

65. Oikonomopoulou K, Diamandis EP, Hollenberg MD, Chandran V. Proteinases and their receptors in inflammatory arthritis: an overview. Nat Rev Rheumatol 2018;14(3):170.

66. Li X, Ma X. The role of heparin in sepsis: much more than just an anticoagulant. Br J Haematol 2017;179(3):389-98.

67. Wildhagen K, Garcia de Frutos P, Reutelingsperger C, Schrijver R. Arest é C, Ortega-Gomez A, et al. Nonanticoagulant heparin prevents histone-mediated cytotoxicity in vitro and improves survival in sepsis. Blood 2014;123:1098-101.

68. Van Bruggen MC, Walgreen B, Rijke TP, Corsius MJ, Assmann KJ, Smeenk RJ, et al. Heparin and heparinoids prevent the binding of immune complexes containing nucleosomal antigens to the GBM and delay nephritis in MRL/Ipr mice. Kidney Int 1996;50(5):155564

69. Warren J, Ward P, Johnson K, Ginsburg I. Modulation of acute immune complex-mediated tissue injury by the presence of polyionic substances. Am J Pathol 1987;128(1):67.

70. Qi L, Zhang X, Wang X. Heparin inhibits the inflammation and proliferation of human rheumatoid arthritis fibroblast-like synoviocytes through the NF-kB pathway. Mol Med Rep 2016;14(4):3743-8.

71. So A, Varisco PA, Kemkes-Matthes B, Herkenne-Morard C, Chobaz-Peclat V, Gerster JC, et al. Arthritis is linked to local and systemic activation of coagulation and fibrinolysis pathways. J Thromb Haemost 2003;1(12):2510-5.

72. Carmassi F, De Negri F, Morale M, Puccetti R, Song K, Chung S. Assessment of coagulation and fibrinolysis in synovial fluid of rheumatoid arthritis patients. Fibrinolysis 1994;8(3):162-71.

73. Busso N, Hamilton JA. Extravascular coagulation and the plasminogen activator/plasmin system in rheumatoid arthritis. Arthritis Rheum 2002;46(9):2268-79.

74. Castellino FJ, Ploplis VA. Structure and function of the plasminogen/plasmin system. Thromb Haemost 2005;93(4):647-54.

75. Belch J, McArdle B, Madhok R, McLaughlin K, Capell H, Forbes $\mathrm{C}$, et al. Decreased plasma fibrinolysis in patients with rheumatoid arthritis. Ann Rheum Dis 1984;43(6):774-7.

76. Senior RM, Skogen WF, Griffin GL, Wilner GD. Effects of fibrinogen derivatives upon the inflammatory response. Studies with human fibrinopeptide B. J Clin Invest 1986;77(3):1014-9.

77. Ginsburg I, De Vries A, Katchalski E. The action of some water-soluble poly-a-amino acids on fibrinolysis. Science 1952;116(3001):156.

78. Pruzanski W, Vadas P, Stefanski E, Urowitz M. Phospholipase A2 activity in sera and synovial fluids in rheumatoid arthritis and osteoarthritis. Its possible role as a proinflammatory enzyme. J Rheumatol 1985;12(2):211-6.

79. Boilard E, Lai Y, Larabee K, Balestrieri B, Ghomashchi F, Fujioka $D$, et al. A novel anti-inflammatory role for secretory phospholipase $\mathrm{A} 2$ in immune complex-mediated arthritis. EMBO Mol Med 2010;2(5):172-87 
80. Bomalaski JS, Clark MA. Phospholipase A2 and arthritis. Arthritis Rheum 1993;36(2):190-8.

81. Masuda S, Murakami M, Komiyama K, Ishihara M, Ishikawa $Y$, Ishii T, et al. Various secretory phospholipase A2 enzymes are expressed in rheumatoid arthritis and augment prostaglandin production in cultured synovial cells. FEBS J 2005;272(3):655-72.

82. Bomalaski JS, Fallon M, Turner RA, Crooke ST, Meunier PC, Clark MA. Identification and isolation of a phospholipase A2 activating protein in human rheumatoid arthritis synovial fluid: induction of eicosanoid synthesis and an inflammatory response in joints injected in vivo. J Lab Clin Med 1990;116(6):814-25.

83. Ginsburg I, Ward PA, Varani J. Lysophosphatides enhance superoxide responses of stimulated human neutrophils. Inflammation 1989;13(2):163-74.

84. Li P, Zheng Y, Chen X. Drugs for autoimmune inflammatory diseases: from small molecule compounds to anti-TNF biologics. Front Pharmacol 2017;8:460.

85. Ginsburg I. Multi-drug strategies are necessary to inhibit the synergistic mechanism causing tissue damage and organ failure in post infectious sequelae. Inflammopharmacology 1999;7(3):207-17.

86. Finkelstein AE, Ladizesky M, Borinsky R, Kohn E, Ginsburg I. Antiarthritic synergism of combined oral and parenteral chrysotherapy. Inflammation 1988;12(4):373-82. 